\title{
Performance Review of Prefabricated Building Systems and Future Research in Australia
}

\author{
Satheeskumar Navaratnam ${ }^{1, *}$, Tuan Ngo ${ }^{1, *}$, Tharaka Gunawardena ${ }^{1}$ (D) and David Henderson ${ }^{2}$ \\ 1 Department of Infrastructure Engineering, The University of Melbourne, Parkville 3010, Australia; \\ tgu@unimelb.edu.au \\ 2 College of Science and Engineering, James Cook University, Townsville 4814, Australia; \\ david.henderson@jcu.edu.au \\ * Correspondence: sathees.navaratnam@unimelb.edu.au (S.N.); dtngo@unimelb.edu.au (T.N.)
}

Received: 11 October 2018; Accepted: 24 January 2019; Published: 3 February 2019

\begin{abstract}
Volumetric prefabricated building construction is growing in most developed countries; for example, in Sweden the market share of prefabricated building systems in the housing industry was more than $80 \%$. However, in Australia only approximately $3-4 \%$ of new building constructions are prefabricated buildings in a year. A major hindrance to the growth of prefab construction in Australia is that systems are developed under commercial and confidential conditions. There are limited publicly-available research and case studies for certifiers, regulators, engineers and academia to provide independent information on the performance, advantages and disadvantages of prefabricated building systems. Independent designers and structural engineers are relying on the strength of the structural and non-structural element, as well as the connections of the prefabricated building systems. This strength is estimated from the "commercial-in-confidence" test of individual components by manufactures, and it might result in undesired outcomes in design. This paper provides an overview of available literature on structural performance, benefits, constraints and challenges of prefabricated building systems. This paper also highlights the research needed on the prefabricated building systems such as full-scale tests, numerical modelling, hybrid simulations, case studies and social and economic assessments. Being supported by sound academic research will increase the market demand for prefabricated building systems in Australia as well as in other countries.
\end{abstract}

Keywords: prefabricated buildings; modular construction; structural performance

\section{Introduction}

In Australia, the prefabricated building system (i.e., pre-cut, panelised, modular, and mobile home building system) has been recognized as a one of the alternative solutions to changing the speed of conventional construction methods at a fast rate. This prefabricated construction system also has been promoted as one of the eight key "visions" to improving the efficiency and performance of the Australian construction industry vision 2020 [1]. Volumetric prefabricated building construction systems comprise modular of volumetric units that are typically manufactured complete with architectural finishes and services at an off-site, quality-controlled factory (See Figures 1 and 2). These modules are then transported and installed on-site as one of many load-bearing structural blocks of the building. Reductions in cost and time are the major advantages offered by the prefabricated building systems when compared to conventional construction methods. Other benefits include improved quality and accuracy in manufacture, speed of installation on-site, and can also be dismantled and reused [2,3]. This form of prefabricated buildings also provides environmental benefits, such as the reduction of construction waste and $\mathrm{CO}_{2}$ emissions, and less disturbance to the building site's 
neighbours by minimizing on-site noise and dust $[4,5]$. These advantages are the driving force within the European building industry for the growth of prefabricated building systems [6-9]. Furthermore, due to population growth, other countries (i.e., US, Canada, Japan, etc.) also use modular construction technology to build houses, apartments, offices, etc. [10,11].

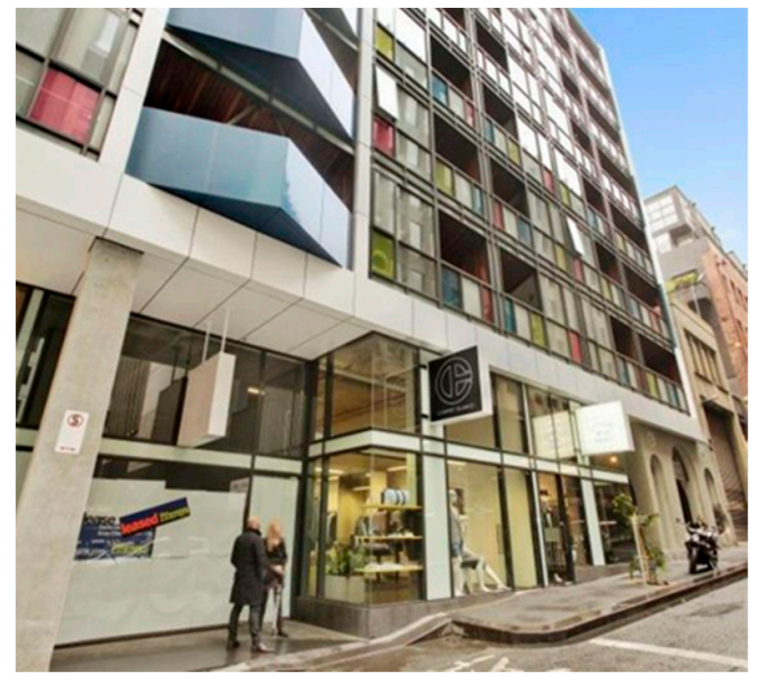

(a)

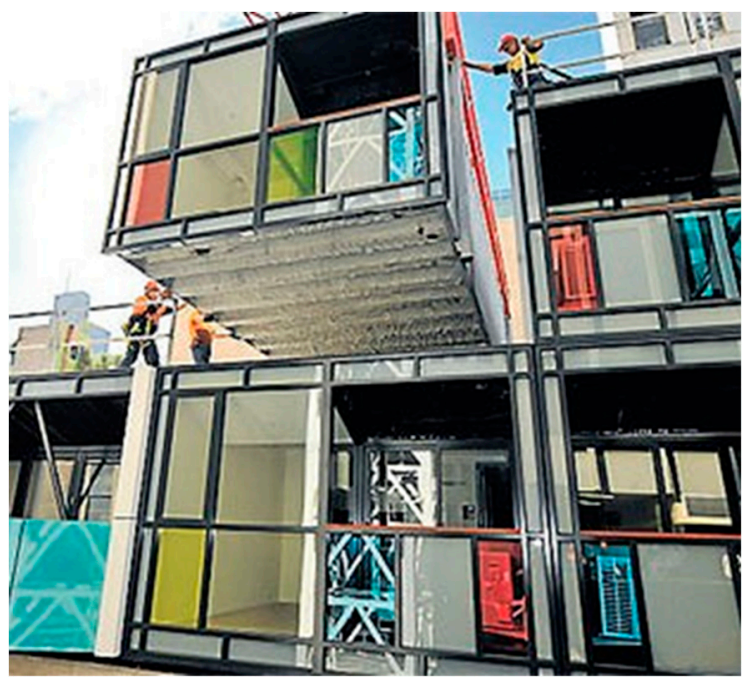

(b)

Figure 1. An image from the modular building 'Little Hero': (a) After being built and occupied; (b) During its on-site assembly (Images by Tuan Ngo).

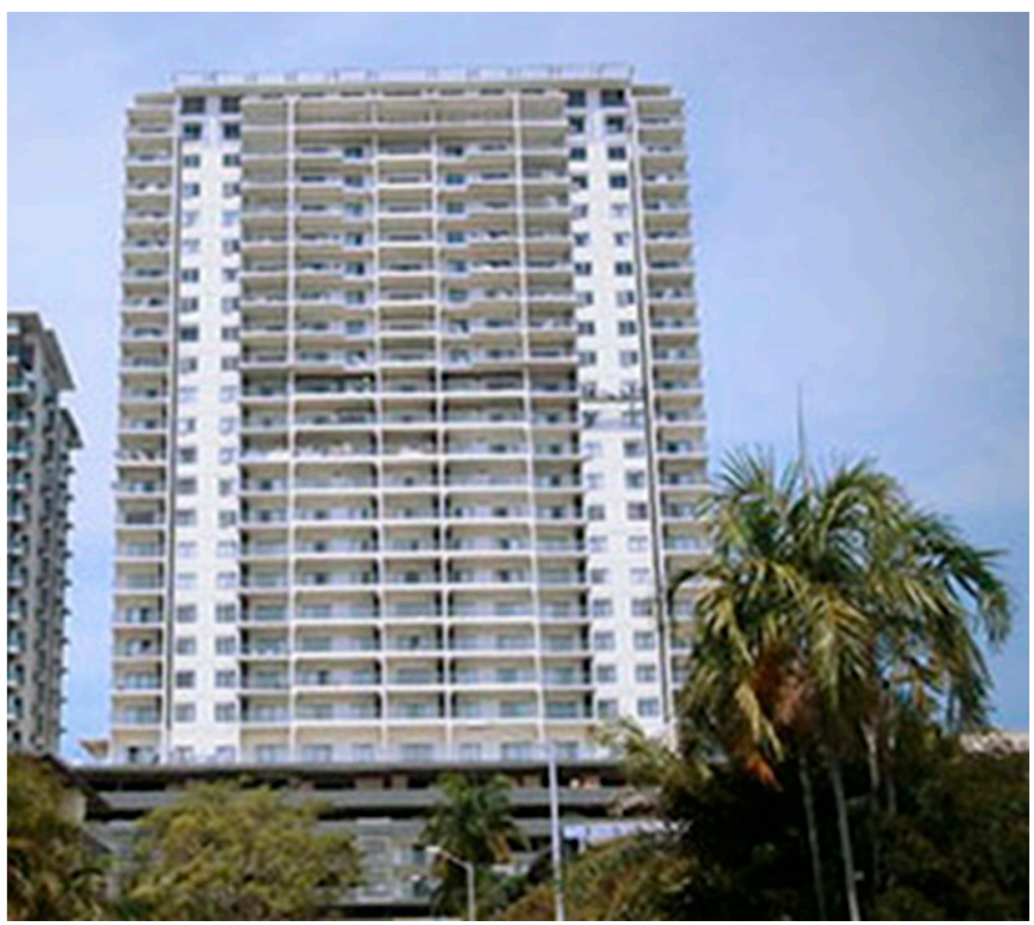

Figure 2. SOHO Apartments in Darwin, Australia [12].

Modular construction technology has been gaining more attention in the building industry over the last few years in Australia. As a result, several low-rise apartments have been built. One example is the 'Little Hero' low-rise apartment building in Melbourne, Australia [3]. However, only a low percentage of all low-rise buildings were built using modular construction or volumetric prefabricated building system $[3,6,13]$. This is in part due to limited knowledge of the applicability, design and 
performance of prefabricated building systems in the building industry and the general public. However, due to recent work by academia, industry and institutions such as prefabAUS in creating awareness of such benefits, the prefab industry is increasing its numbers, especially in the education and public services sectors. The Permanent Modular School Buildings Program (PMSB), an initiative of the Victorian School Building Authority (VSBA) of Australia, has commenced the replacement of old school buildings with newly-built modular classroom buildings targeting hundreds of schools around Victoria, Australia where already 30 modular school buildings have been completed and handed over. Figure 3 shows some of the exterior and interior images of those newly-built facilities provided by the PMSB program.

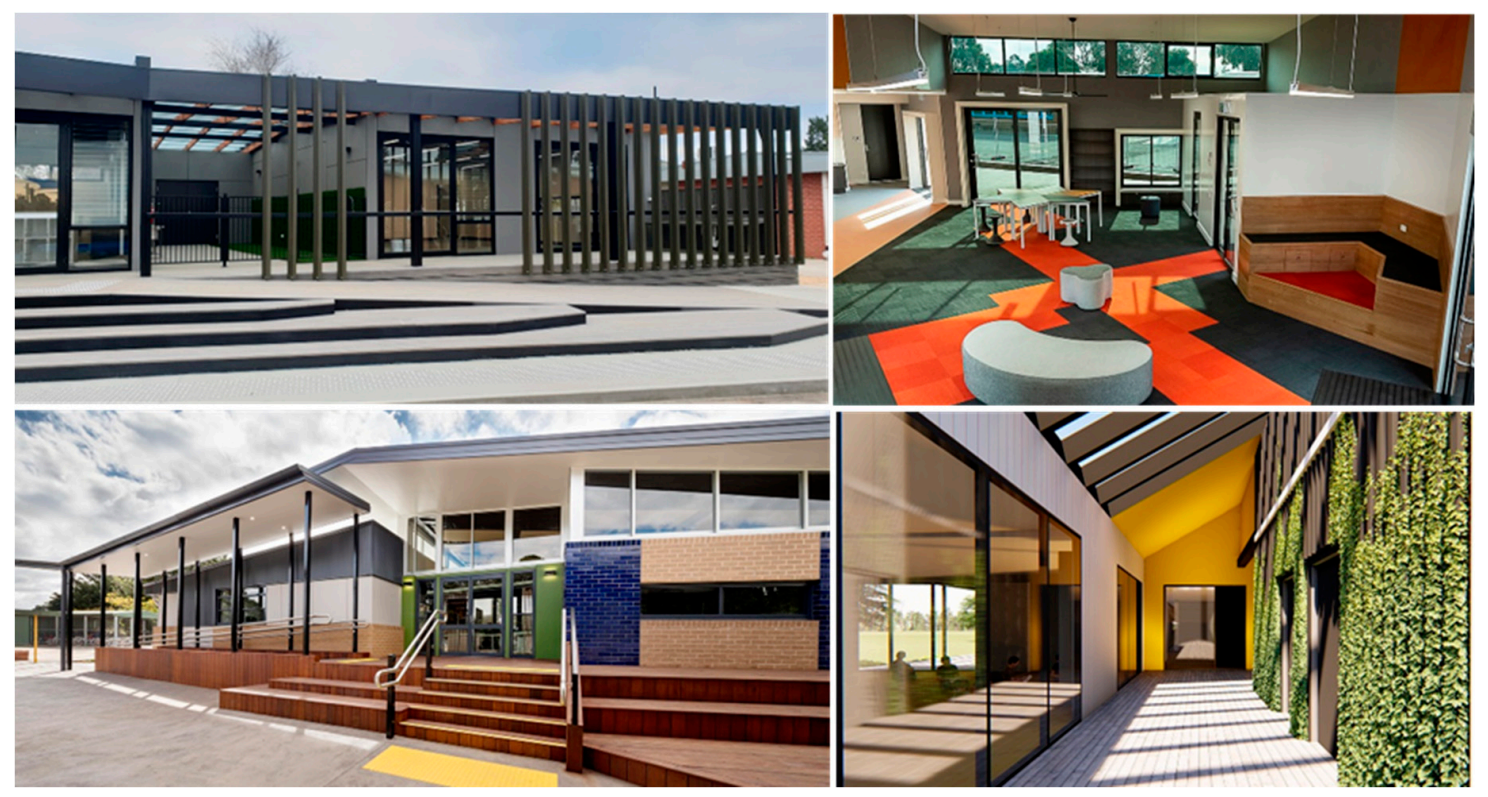

Figure 3. New modular schools built by the PMSB program of VSBA in 2018-Mt Waverly Heights Primary School, Glengala Primary School, Yallourn North Primary School and Beaumaris North Primary School respectively (Victorian School Building Authority [VSBA], (C) State of Victoria, Department of Education and Training, 2018) [14].

Similarly, many public spaces in Australia such as new railway stations, police stations, healthcare facilities (Figure 4) and community centres are now being built using volumetric modular construction and other prefabricated methods with the assistance of the Australian government. Therefore, it is quite evident from the recent advancements of the prefab industry in Australia how the collaboration of industry, academia and government authorities can heavily impact the growth of an industry for the ultimate benefit of society. However, limited awareness on the performance, benefits, skills and knowledge required for prefabrication design and construction practice need to be developed and strengthened to increase the number of prefabricated buildings and constructions in Australia. This paper provides an overview of past research noting the limitations in the Australian context and offers some recommendations on targeted research needed in the prefabricated building system. 


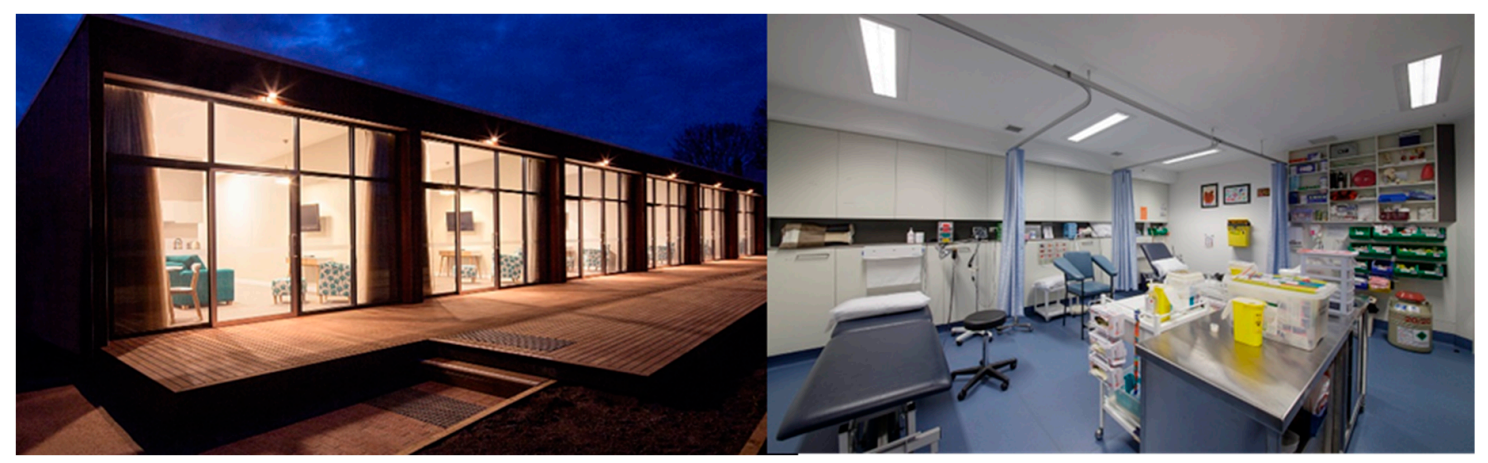

Figure 4. Images from healthcare facilities built using modular construction in Australia, Left-Ballarat Health Cancer Care Unit, Right-Pascoe Vale Health (Prebuilt Pty. Ltd., 2018) [15].

\section{Previous Research Studies on the Benefits}

\subsection{Cost and Time}

Reducing cost and time are major anxieties for both consumers and manufactures in the building industry. When compared to conventional construction methods, the prefabricated construction system provides significant reductions in both cost and time [2,4,5,16-19]. In a prefabricated construction system, the phases of site preparation and construction of the modules can be run simultaneously, while in conventional construction, the construction phase happens after the site preparation phase $[4,17,20]$. With construction phase activities occurring at the same time as the prefabricated construction, reductions in construction time of about $40 \%$ occur, when compared to conventional construction practices $[4,17,20-23]$.

However, pre-project planning is quite intensive for prefabricated construction systems, as their design has different complexities from conventional design. For example, features such as when modules are lifted, transported to the final project site, placed on the foundation, and joined to form the building need to be taken into account in the design phase. This requires more engineers, quality controllers and skilled labourers [24]. These requirements will increase the cost and duration of the design phase, but they reduce the cost and time of the on-site construction phase significantly in prefabricated construction compared to conventional construction. Furthermore, the construction activities in conventional construction are significantly affected by any climate change or weather condition interruptions. Meanwhile, in the prefabricated construction method, these kinds of interruptions were negligible, as the majority, i.e., about $80-90 \%$, of construction activities happen in a factory. This also reduces the construction time and total cost of projects using the prefabricated construction method when compared to conventional construction methods.

In prefabricated construction, the manufacturer can order material in bulk and fabricate several modules at same time. This provides lower prices from suppliers and reduces the number of labours and transportations. This will result in savings in cost and time of the project. Moreover, prefabricated construction reduces the number of on-site laborers, which reduces the total labour cost by about $25 \%$ compared to traditional construction methods [17,25-28]. However, these cost and time benefits are not very clear due to the lack of access to confidential information of projects (i.e., financial and actual project plan), as well as to the use of new technology and modern machineries [26,29-31].

\subsection{Other Benefits}

In conventional construction, there are several safety issues, including working at height, congestion, severe weather work place accidents, neighbouring construction operations, etc. However, these problems were reduced by about $80 \%-85 \%$ in prefabricated construction, as the majority of construction works, i.e., about $80 \%$, occurs in factories $[2,17,25-31]$. This construction in factories provides consistent products, as they are repetitive processes, and are typically undertaken with 
automation $[2,30,32,33]$. Prefabricated construction systems also provide the environmental benefit of less construction waste. This is because $80 \%$ of construction operations take place in a factory, where waste materials can be controlled/reused/recycled $[2,4,17,20,21,23,25-31,34]$. Prefabricated building modules can be disassembled, relocated, or retrofitted and renovated to be used in other projects, which reduces disposal waste.

A case study by Lawson [2] highlighted the fact that in prefabricated building construction, the neighbouring buildings are not affected as much as in traditional building construction methods, as noise and disruption are reduced by $30-50 \%$. Lawson [2] also showed the prefabricated modular construction reduces landfill by a factor of at least 70\%. A study by Aye [19] shows that the reuse of materials in prefabricated steel buildings saves about $81 \%$ of embodied energy and $51 \%$ of materials by mass (Figure 5). Prefabricated houses also reduce $\mathrm{CO}_{2}$ operating emissions by approximately $50 \%$ in annual households [5]. Studies by Matic [35] investigated the energy refurbishment of existing buildings, and their conversion to energy efficient buildings with minimized loads. This study found a significant reduction of thermal and cooling loads after refurbishment of existing buildings, when compared to those buildings' pre-furbished data. These research and case studies [2,4,35-41] indicate that prefabricated construction systems contribute significantly to improving environmental sustainability in the construction industry.

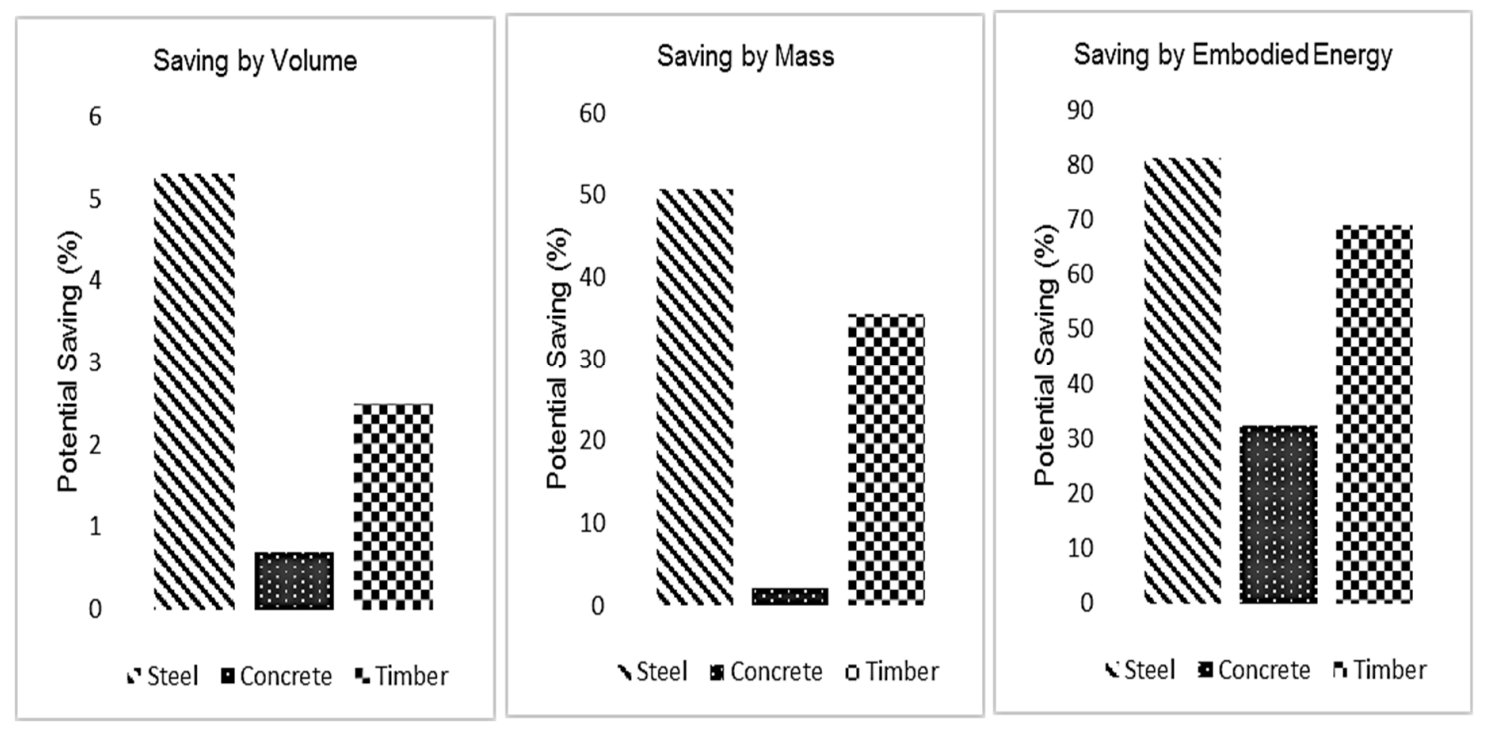

Figure 5. Total volume, mass and embodied energy of concrete and prefabricated steel and timber building scenarios, with percentage of potential savings achieved from the reuse of materials through Modular Construction [19].

\section{Structural Performance of Prefabricated Building Systems}

The structural performance of conventional structures such as steel, concrete and timber-frames under any natural (i.e., wind load, earthquake load, bushfire) and manmade (i.e., bomb-blast, vehicle impact, etc.) loading has been evaluated by many researchers from around the world and incorporated into the design of a range of approaches. However, structural performance data of prefabricated building structures is limited, as little detail of engineering research and few case studies have been published $[3,42,43]$. The structural design approach should ensure the stability of the building structure under these natural and manmade loads, transferring such loads to the foundation through their structural elements, non-structural elements and inter-component connections. Although, these approaches have proved to be adequate, complex structural systems such as timber-framed houses, non-conventional structures and prefabricated buildings may give rise to non-optimal designs. This is due to a lack of knowledge in the load sharing and load transfer of structural systems. The load sharing and load transfer in prefabricated building can be complex, as the system uses multiple 
inter-component connections between the modules, which can be influenced by tolerances in the installation procedure. The vertical and lateral loads are transferred generally through inter-component connections and stabilizing elements such as vertical bracing or core walls. In prefabricated systems with load-bearing walls, the axial load is transferred via direct wall-to-wall bearing. Plasterboard or similar boards are often attached to the exterior of walls, and these boards prevent the C-sections (i.e., generally used in the wall panel) from buckling in the in-plane direction of the wall [2]. The tie forces at the corner of the modules provide resistance to accidental loads, and the accidental limit state is generally taken as the self-weight plus one-third of the imposed load [2].

A case studies by Lawson [2] recommended that the following key factors should be taken into account in the design of modular buildings: (1) influence of installation eccentricities and manufacturing tolerances on the additional forces and moments in the walls; (2) second-order effects due to sway stability of the group of modules; (3) mechanism of force transfer of horizontal loads to the stabilizing system; (4) robustness to accidental actions for modular systems; (5) the minimum horizontal force in any tie between the modules is taken as not less than $30 \%$ of the total load acting on the module and not less than $30 \mathrm{kN}$. Gunawardena [42] have analysed the static and dynamic behaviour of the structure using finite-element analysis techniques with the aid of a three-dimensional (3D) computer model. Their study highlighted that the torsional or twisting effects are a major problem for the designers of these type of buildings. Results also show that elevator shafts can be flexibly shifted around the plan without causing adverse torsional effects to the structure.

A performance-based design approach was imposed in many countries such as Australia, New Zealand, and the USA. This approach requires an independent engineering design for conventional and non-conventional houses such as modular houses. The independent engineering design involves laboratory tests and full-scale tests on the individual components (i.e., wall, ceilings, roof, connections, etc.), as well as structural analyses using finite element software. This approach is still adopted for the structural design and construction of houses in Australia. Therefore, several full-scale and individual components tests were conducted, including timber-framed houses and prefabricated steel-framed panelised building systems [44]. In Australia, the prefabricated modular houses and building design are based on wind, fire and earthquake standards, i.e., AS 1170.2 [45], AS 1170.4 [46], AS 1530.4 [47] and AS 5113 [48], as well as the National Construction Code [49]. These standards are developed by a number of research publications, case studies, laboratory tests, full-scale tests and structural analyses. However, there are no specific standards or recommendations for prefabricated building design, as there are limited engineering research and case studies which evaluate the performance of prefabricated building systems compared to those of conventional building systems.

\subsection{Fire Resistance and Acoustic Performance}

Fire safety is a major concern after the building collapse at the World Trade Centre (in 2001, New York) and the Grenfell Tower (in 2017, London). These failures have led to more research and fire safety testing on structural and non-structural elements as well as their connections. The collapses of these buildings have also led to changes in building standards and to the banning of some building materials such as combustible claddings. In Australia, buildings are facing the danger of bushfires (e.g., Black Saturday in Victoria 2009, Ash Wednesday in Victoria 1983, Black Friday in Victoria 1939, Black Tuesday in Tasmania 1967, and the Gippsland fires and Black Sunday in Victoria in 1926) and their associated costs in terms of significant insurance payout and loss of life [50,51]. Therefore, the fire resistance of buildings and their elements is important.

In prefabricated modular buildings, double-layer walls and floor-ceilings are generally used. The fire barriers and protection are installed between the modules and internal face of the wall to prevent the spread of smoke or fire in the cavity and between the modules [2].

The double-layer walls and floor/ceiling offer significant resistance to airborne and impact sound. Thin concrete floor screed placed either on the light steel floor or as a composite slab between 
the walls or edge beams in the prefabricated building system also provides the additional sound reduction and floor stiffness to minimize vibrations [2]. However, the manufacturing and construction of prefabricated building systems vary between countries, as well as some regions within the country. This difference will create variations in the fire and acoustic performance of prefabricated building systems in Australia compared to those in the Lawson [2] case studies.

Moreover, composite materials, light weight Structural Insulated Panels (SIPs), Cross Laminated Timber (CLT), and Concrete-filled steel hollow sections have played a significant role in the prefabricated construction industry over the past years [51-54]. Full-scale fire testing and computational fluid dynamics by Nguyen [53] highlighted the fact that prefabricated, lightweight aerated concrete (PLAC) panels in the modular construction achieved 30 minutes' fire resistance and provided low thermal conductivity compared to normal concrete product. Other fire tests on CLT beams show that the current zero-strength layer fails to capture the necessary physics for robust predictions of structural responses under non-standard heating, and recommended that more detailed thermo-mechanical, cross-section analyses are needed to determine the structural implications of real fire exposure [44]. These studies [52-56] assess the structural response of the individual elements and connections under fire. The fire rating of individual elements and connections could vary when compared to whole structure. Therefore, the structural responses of whole prefabricated buildings or modules under fire conditions need to be evaluated.

\subsection{Performance of the Structure under Earth Quake and Wind Load}

The finished panels or modules of a prefabricated system are transported to the site and erected both horizontally and vertically using horizontal and vertical connections [57-59]. Lateral bracings or core walls are used to achieve the lateral stability of the structure [2,42]. Annan [57] designed and modelled typical braced frames of Modular Steel Buildings to evaluate their inelastic behaviour under seismic loads. The results showed that the reserve strength of Modular Steel Building braced systems was greater than that of traditional braced systems (i.e., specified in the Canadian code). This study recommended that the unique detailing (i.e., frame type, special vertical connections at column) requirements of Modular Steel Building braced systems should be taken into account during the design phase to improve seismic response.

Further, a study carried out by Gunawardena et al. [42] investigated the earthquake performance of corner-supported, multistorey modular structures. The outcome of a capacity spectrum analysis (Figure 6) showed that the analysed 10-storey modular structure was past its linear deformation zone at its performance points against all six earthquake time histories that it was analysed against. However, the performance points were also far below the full capacity of the structure. Therefore, it was concluded that the structure analysed in this study performed in the 'Immediate Occupancy' to 'Life Safety' range as per the performance levels introduced in FEMA 356 [60].

Windstorms is the one of major natural hazards in Australia as well as other countries such as US, Canada, UK, India, etc. Many studies on structural responses to wind loading for conventional building structures have been published. Limited research and few case studies are available on prefabricated building system responses. In prefabricated building, lateral wind loads are resisted and transferred by bracing elements and/or sheathing the walls, and then conveyed to the foundation $[61,62]$. Bathon [63] developed a building using prefabricated wood-concrete-composite panels (see Figure 7). The structural response of this system was assessed under hurricane loading conditions with wind speeds up to $400 \mathrm{~km} / \mathrm{h}$. Although this current paper is focusing on volumetric prefabricated buildings, the study by Bathon [63] focused on panel-based prefabricated buildings, highlighting the importance of the connections between the prefabricated components. His results demonstrated that the lateral load on the floor level was $429 \mathrm{kN} / \mathrm{m}$ (see Figure 8), and highlighted that this wood-concrete-composite panels system provided more structural stability under wind loads as well as seismic loads. Overall, this wood-concrete-composite panels system allows for a cost-efficient hurricane-proof design and 
provides more resistance under seismic loads compared to contemporary American and European building systems.

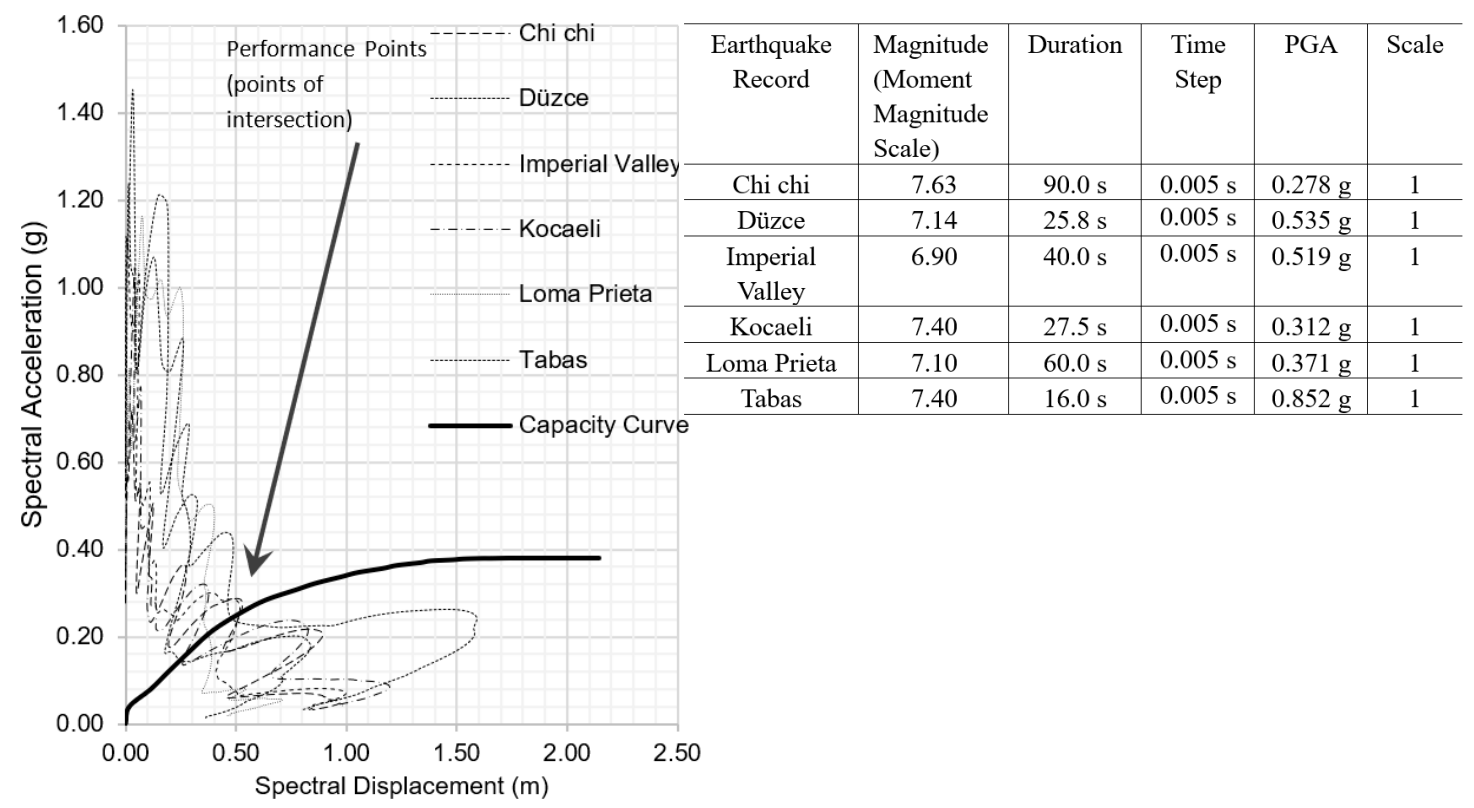

Figure 6. Outcome of the capacity spectrum analysis: $5 \%$ damped demand curves against the capacity curve [42].
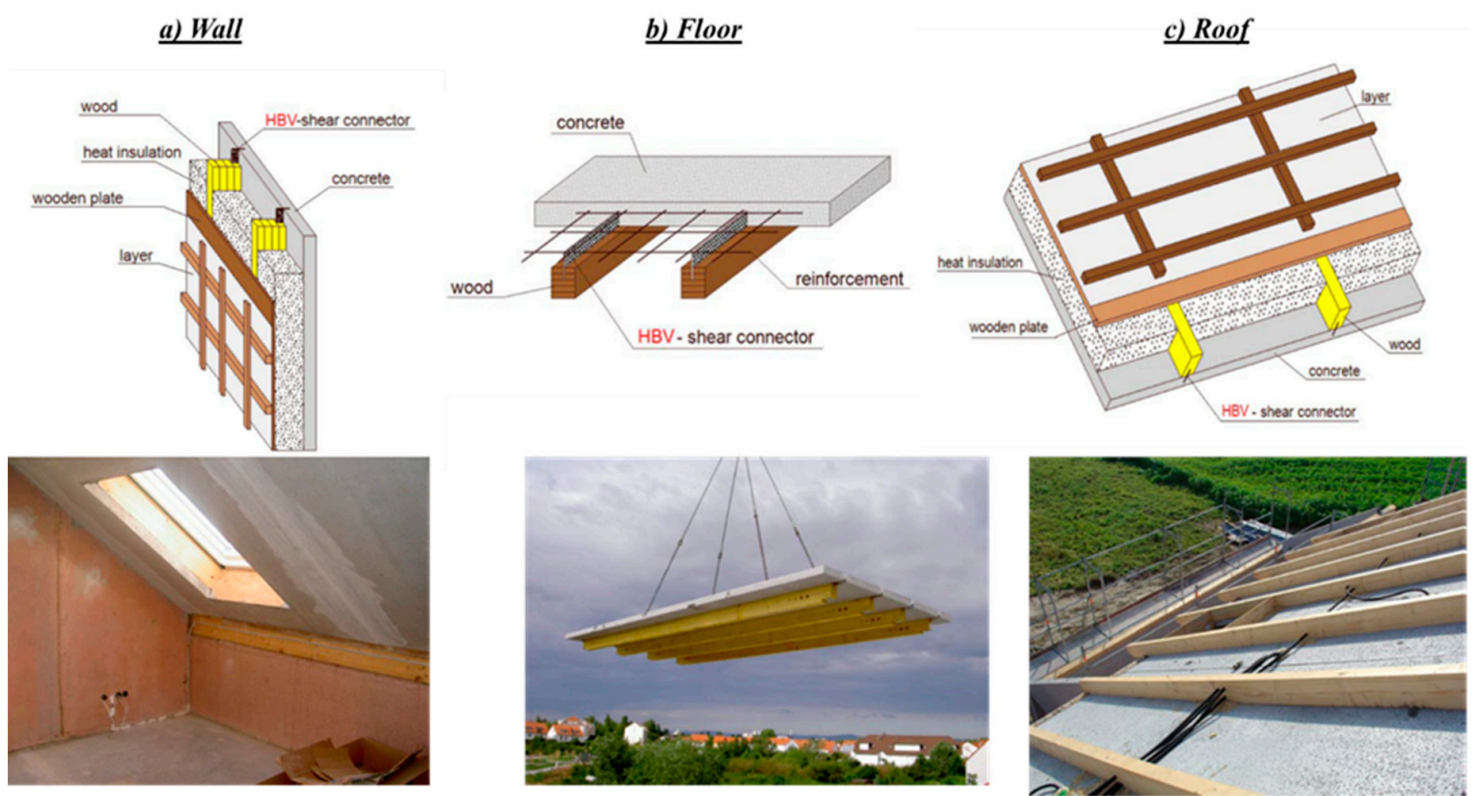

Figure 7. Elements of wood-concrete-composite buildings [63]: (a) Wall; (b) Floor; (c) Roof. 


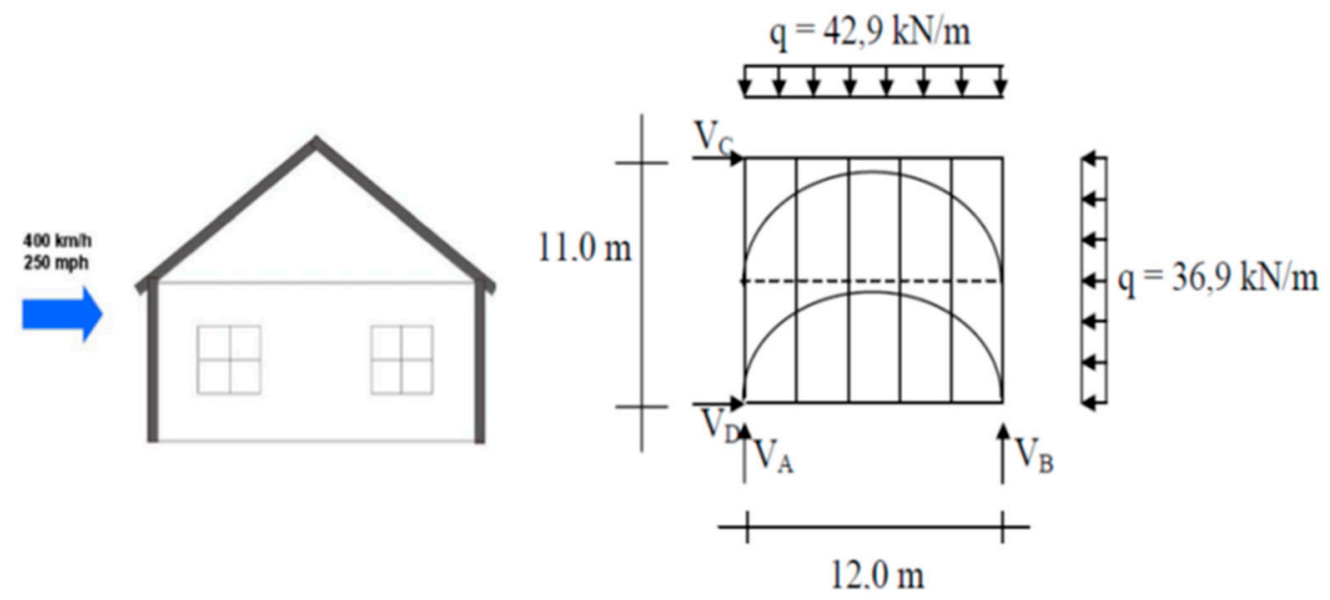

Figure 8. Wind loads based on hurricane conditions [63].

A full-scale simulated wind load test was conducted on a prefabricated panelised steel framed single storey building at the Cyclone Testing Station, Australia [64]. The testing evaluated the transmission of load sharing (i.e., uplift and lateral loads) across the various panelised elements such as the wall, ceiling, roof, connections, etc. The results show that the prefabricated panelised steel framed building performed well when subjected to static loads simulating the lateral and uplift for $50 \mathrm{~ms}^{-1}$. However, during load cycling to simulate cyclonic wind load fluctuations, failure occurred at the wall panel subfloor interface. This was due in part to the load cycles accentuating the eccentric connection design resulting in fatigue of the rods. A similar type of prefabricated panelised steel framed house structural system is currently being developed with new construction material, non-conventional connections and advanced technology, and being built in some parts of Australia. Thus, it essential to assess the structural responses of this type of building system under wind loads.

\section{Constraints, Challenges and Future Research}

Project planning is one of the biggest challenges in prefabricated building construction, as several factors must be considered, such as incorporating different components within a module when they are lifted, transformation, placed on the foundation, and assembled the building $[4,65]$. This requires clear scope, more experience design and planning engineers, and skilled manufacturing, and it also consumes more time and money. However, the accomplishment time of modular houses or high-rise buildings was still less than that of conventional buildings [32]. Ramaji and Memari [66] have highlighted that when the number of stories increases in a prefabricated modular building, the time savings decrease considerably. This is because of system becomes more complex, causing more challenges in project planning. Other constrains in the prefabricated system are the module dimensions, the inability to make changes onsite, and transportation, which are the most important factors needing to be considered before and after the design the structure.

Structural performance and the strength of the structural and non-structural elements and their connections used in the prefabricated construction system are important to the design of the system. Astonishingly, there has been limited published research on this system, because most of this prefabricated system consists of patented elements. Also, prefabricated system development has been undertaken under commercial and confidential conditions. The designers rely on the strength of the structural and non-structural elements and their connections specified by manufacturers based on commercial-in-confidence testing. In Australia, most of these tests were based on international standards such as ASTM and European standards. This is because, in Australia, there are no specific testing standards for most prefabricated structural and non-structural elements. Moreover, the prefabricated structural design follows the normal conventional structural design standards. But prefabricated structural systems are complex, non-conventional systems, and they use several 
non-conventional connections. Therefore, Australian design standards need to be developed to include the design specifications and recommendations for prefabricated structures. This requires more research and case studies.

Furthermore, individual component testing (i.e., wall, ceiling, roof, connections), full-scale testing and numerical models are the tools used to assess the performance of prefabricated building structures. There is limited number of tests, and few numerical models have been conducted by manufactures and researchers. In addition to this, there is only one full-scale test to have been conducted on prefabricated, panelised, steel-framed housse [64]. Full-scale tests are important to assess the performance of structures, as there are inherent redundancies in structural behaviour when comparing individual component tests and full-scale tests [67]. This could create variations in the design of wind, earthquake and fire-resistant loads that are estimated from simplification load transmissions. The current uses of new materials and construction types in prefabricated construction systems also need to assess their strength and structural system responses via sub assembly tests as well as full-scale tests. The fire ratings of materials used in the construction industry are critical for the performance of prefabricated building systems. For example, the CLT panels and façade system used in the prefabricated system face issues in term of their fire ratings. Therefore, future research needs to be focused on evaluations of the structural performance of prefabricated buildings via full-scale tests, numerical modelling and hybrid simulation. Hybrid simulations offer a more efficient and suitable way to assess how large prefabricated buildings respond to seismic loading by combining physical testing and computer modelling. Researchers and the building industry should ensure that the outcomes of future research are available for the public and design engineers. The outcomes should also be used in construction practices and design methodologies to increase the prevalence of prefabricated buildings in Australia.

\section{Conclusions}

In this paper, the performance of prefabricated building systems has been reviewed from the available resources. This review shows that prefabricated building systems and construction hold high potential to improve the efficiency and performance of the Australian construction industry in a more sustainable sense. However, more research studies are needed to ensure that these prefab building systems and construction deliver substantial benefits economically, and in an environmentally- and socially-friendly manner. Here are some suggestions to increase the market demand and to contribute to the development of prefabricated building systems in Australia.

- The limitations of transportation, regulations, and special traffic control in the construction area are the main factors to be considered in transportation planning. Therefore, more case studies are needed to evaluate project planning, scheduling, and the cost of small- and large-scale projects.

- More research and case studies are needed to develop and include the design specifications and recommendation for prefabricated structures according to Australian design standards.

- Previous study has highlighted that most often, structural performance of prefabricated building systems is assessed by individual component testing and numerical models. There could be an inherent redundancy in the structural behaviour when the structural response between individual components and the whole structure are compared. Therefore, numerical modelling, hybrid simulations and full-scale tests need to be conducted on prefabricated whole buildings to evaluate the structural responses and performance under fire, wind and earthquake loads.

- A lack of awareness on the performance, benefits, and affordability design and techniques provided by the prefabricated systems is a major challenge for the marketing of prefabricated building construction in Australia. This could have been achieved through social and economic research. This research should focus on the following activities, such as questionnaires, workshops, conferences and media interviews.

- Although a great deal of previous academic research has proven the sustainability aspects of prefabricated construction, this knowledge needs to be more effectively communicated to the 
general public. This needs to be accompanied by real case studies on public infrastructure projects where the general public benefits from the performance of prefabricated structures.

- The skills and knowledge required for prefabrication design and construction practices in Australia need to be developed and strengthened through relevant educational courses, workshops, conferences and vocational training. Also, universities, TAFE and vocational education institutes should consider including prefabrication design and construction in their courses. This will increase the professional skills and knowledge required for the design and construction practices, as well as increasing their productivity.

- The government and building industry need to encourage the building of some trademark structures similar to the 'Little Hero' low-rise apartment building in Melbourne. This will increase the market demand and development of prefabricated building systems in Australia.

Author Contributions: Conceptualization, S.N., and T.N.; Funding acquisition, T.N.; Investigation, S.N., T.G., D.H.; Writing—original draft, S.N., D.H., and T.G.; Writing—review \& editing, S.N., D.H., T.G. and T.N.

Funding: This research was funded by the Australian Research Council (ARC) Training Centre for Advanced Manufacturing of Prefabricated Housing (Project ID: IC150100023) and the Asia Pacific Research Network for Resilient and Affordable Housing (APRAH).

Acknowledgments: The authors gratefully acknowledge the funding support of the ARC Training Centre for Advanced Manufacturing of Prefabricated Housing and the Asia Pacific Research Network for Resilient and Affordable Housing (APRAH) of the Department of Infrastructure Engineering, University of Melbourne.

Conflicts of Interest: The authors declare no conflict of interest.

\section{References}

1. Hampson, K.D.; Brandon, P. Construction 2020-A Vision for Australia's Property and Construction Industry; CRC Construction Innovation: Brisbane, Australia, 2004.

2. Lawson, R.M.; Ogden, R.G.; Bergin, R. Application of modular construction in high-rise buildings. J. Archit. Eng. 2012, 18, 148-154. [CrossRef]

3. Gunawardena, T.; Ngo, T.D.; Mendis, P.; Alfano, J. Innovative flexible structural system using prefabricated modules. J. Arch. Eng. 2016, 22, 05016003. [CrossRef]

4. Kamali, M.; Hewage, K. Life cycle performance of modular buildings: A critical review. Renew. Sustain. Energy Rev. 2016, 62, 1171-1183. [CrossRef]

5. Paya-Marin, M.A.; Lim, J.; Sengupta, B. Life cycle energy analysis of a modular/ off-site building school. Am. J. Civ. Eng. Archit. 2013, 1, 59-63. [CrossRef]

6. Blismas, N.; Wakefield, R. Drivers, constraints and the future of offsite manufacture in Australia. Construct. Innov. Inf. Process Manag. 2009, 9, 72-83. [CrossRef]

7. Bildsten, L. Exploring the opportunities and barriers of using prefabricated house components. In Proceedings of the 19th Conference of the International Group of Lean Construction (IGLC), Lima, Peru, 13-15 July 2011.

8. Nadim, W.; Goulding, J.S. Offsite production: A model for building down barriers: A European construction industry perspective. Eng. Construct. Archit. Manag. 2011, 18, 82-101. [CrossRef]

9. Pan, W.; Gibb, A.G.F.; Dainty, A.R.J. Perspectives of UK housebuilders on the use of offsite modern methods of construction. Construct. Manag. Econ. 2007, 25, 183-194. [CrossRef]

10. Cameron, P.J.; Di Carlo, N.G. Piecing Together Modular: Understanding the Benefits and Limitations of Modular Construction Methods for Multifamily Development. Master's Thesis, Massachusetts Institute of Technology, Cambridge, MA, USA, 2007.

11. Steinhardt, D.A.; Manley, K. Exploring the belief of Australian prefabricated house builders. Construct. Econ. Build. 2016, 16, 27-41. [CrossRef]

12. Gunawardena, T.; Karunaratne, R.; Mendis, P.; Ngo, T. Prefabricated Construction Technologies for the Future of Sri Lanka's Construction Industry. In Proceedings of the 7th International Conference on Sustainable Built Environment (ICSBE), Earl's Regency Hotel, Kandy, Sri Lanka, 16-18 December 2016.

13. Blismas, N. Off-Site Manufacture in Australia: Current State and Future Directions; Cooperative Research Centre for Construction Innovation: Brisbane, QLD, Australia, 2007. 
14. Victorian School Building Authority [VSBA]; @ State of Victoria (Department of Education and Training). Permanent Modular School Buildings Program. 2018. Available online: https: / www.schoolbuildings.vic. gov.au/Pages / Permanent-Modular-School-Buildings-Program.aspx (accessed on 11 October 2018).

15. Prebuilt Pty. Ltd. Ballarat Health Cancer Unit. 2018. Available online: https://commercial.prebuilt.com.au/ our-projects/health/ballarat-health-cancer-care-unit/ (accessed on 11 October 2018).

16. Kozlovská, M.; Kaleja, P.; Struková, Z. Sustainable construction technology based on building modules. Adv. Mater. Res. 2014, 1041, 231-234. [CrossRef]

17. Haas, C.T.; O'Connor, J.T.; Tucker, R.L.; Eickmann, J.A.; Fagerlund, W.R. Prefabrication and Pre-Assembly Trends and Effects on the Construction Workforce; Report; Center for Construction Industry Studies, University of Texas: Austin, TX, USA, 2000.

18. Pasquire, C.L.; Gibb, A.G.F. Considerations for assessing the benefits of standardization and pre-assembly in construction. J. Financ. Manag. Prop. Constr. 2002, 7, 151-161.

19. Aye, L.; Ngo, T.; Crawford, R.H.; Gammampila, R.; Mendis, P. Life cycle greenhouse gas emissions and energy analysis of prefabricated reusable building modules. Energy Build. 2012, 47, 159-168. [CrossRef]

20. Kawecki, L.R. Environmental Performance of Modular Fabrication: Calculating the Carbon Footprint of Energy Used in the Construction of a Modular Home. Ph.D. Thesis, Arizona State University, Tempe, AZ, USA, 2010.

21. Mah, D.E. Framework for Rating the Sustainability of The Residential Construction Practice. Ph.D. Thesis, University of Alberta, Edmonton, AB, Canada, 2011.

22. Lawson, R.M.; Ogden, R.G. Sustainability and process benefits of modular construction. In Proceedings of the 18th CIB World Building Congress, Salford, UK, 10-13 May 2010; pp. 38-51.

23. Zenga, M.; Javor, A. Modular Homes: The Future Has Arrived; Fideli Publishing: Paragon, Indiana, 2008.

24. Schoenborn, J.M. A Case Study Approach to Identifying the Constraints and Barriers to Design Innovation for Modular Construction. Master's Thesis, Virginia Polytechnic Institute and State University, Blacksburg, VS, USA, 2012.

25. Haas, C.T.; Fagerlund, W.R. Preliminary Research on Prefabrication, Pre-Assembly, Modularization and Off-Site Fabrication in Construction; Report; The Construction Industry Institute, The University of Texas at Austin: Austin, TX, USA, 2002.

26. $\mathrm{Na}, \mathrm{L}$. Investigation of the Designers' and General Contractors' Perceptions of Offsite Construction Techniques in the United States Construction Industry. Ph.D. Thesis, Clemson University, Clemson, SC, USA, 2007.

27. Quale, J.; Eckelman, M.J.; Williams, K.W.; Sloditskie, G.; Zimmerman, J.B. Construction matters: Comparing environmental impacts of building modular and conventional homes in the United States. J. Ind. Ecol. 2012, 16, 243-253. [CrossRef]

28. Chiu, S.T.L. An Analysis on the Potential of Prefabricated Construction Industry. Ph.D. Thesis, The University of British Columbia, Vancouver, BC, Canada, 2012.

29. Chiang, Y.H.; Chan, E.H.W.; Lok, L.K.L. Prefabrication and barriers to entry-A case study of public housing and institutional buildings in Hong Kong. Habitat. Int. 2006, 30, 482-499. [CrossRef]

30. Lawson, R.M.; Ogden, R.G. "Hybrid" light steel panel and modular systems. Thin Wall Struct. 2008, 46, 720-730. [CrossRef]

31. Pan, Y.; Wong, F.K.W.; Hui, E.C.M. Application of industrialized housing system in China: A Chongqing study. In Modeling Risk Management in Sustainable Construction, Computational Risk Management; Springer: Berlin, Germany, 2011; pp. 161-168.

32. Cartz, J.P.; Crosby, M.; Symonds, D.C. Building high rise modular homes. Struct. Eng. 2007, 85, $20-21$.

33. Rogan, A.L.; Lawson, R.M.; Bates-Brkljac, N. Value and Benefits Assessment of Modular Construction; Report; Steel Construction Institute: Berkshire, UK, 2000.

34. Gibb, A.; Isack, F. Re-engineering through pre-assembly: Client expectations and drivers. Build. Res. Inf. 2003, 31, 146-160. [CrossRef]

35. Matic, D.; Calzada, J.R.; Todorovic, M.S.; Erić, M.; Babin, M. Cost-Effective Energy Refurbishment of Prefabricated Buildings in Serbia. In Cost-Effective Energy Efficient Building Retrofitting; Elsevier: Cambridge, UK, 2017; pp. 455-487. 
36. Salavatian, S.; D'Orazio, M.; Di Perna, C.; Di Giuseppe, E. Assessment of Cardboard as an Environment-Friendly Wall Thermal Insulation for Low-Energy Prefabricated Buildings. In Sustainable Building for a Cleaner Environment; Springer: Cham, Switzerland, 2019; pp. 463-470.

37. Minunno, R.; O'Grady, T.; Morrison, G.; Gruner, R.; Colling, M. Strategies for Applying the Circular Economy to Prefabricated Buildings. Buildings 2018, 8, 125. [CrossRef]

38. Chang, Y.; Li, X.; Masanet, E.; Zhang, L.; Huang, Z.; Ries, R. Unlocking the green opportunity for prefabricated buildings and construction in China. Resour. Conserv. Recycl. 2018, 139, 259-261. [CrossRef]

39. Hong, J.; Shen, G.Q.; Li, Z.; Zhang, B.; Zhang, W. Barriers to promoting prefabricated construction in China: A cost-benefit analysis. J. Clean. Prod. 2018, 172, 649-660. [CrossRef]

40. Pons, O. Assessing the sustainability of prefabricated buildings. In Eco-Efficient Construction and Building Materials: Life Cycle Assessment (LCA), Eco-Labelling and Case Studies; Elsevier: Cambridge, UK, 2014; pp. 434-456.

41. Waskett, P. Current Practice and Potential Uses of Prefabrication; DTI Construction Industry Directorate: Watford, UK, 2001.

42. Gunawardena, T.; Ngo, T.D.; Mendis, P. Behaviour of multi-storey prefabricated modular buildings under seismic loads. Earthq. Struct. 2016, 11, 1061-1076. [CrossRef]

43. Lacey, A.W.; Chen, W.; Hao, H.; Bi, K. Structural response of modular buildings-An overview. J. Build. Eng. 2018, 16, 45-56. [CrossRef]

44. Boughton, G.N.; Parackal, K.; Satheeskumar, N.; Henderson, D.J. Development of a Full-Scale Structural Testing Program to Evaluate the Resistance of Australian Houses to Wind Loads. Front. Built Environ. 2017, 3, 21. [CrossRef]

45. Standards Australia. Structural Design Actions. Part 2: Wind Actions; AS 1170.2; Standards Australia: New South Wales, Australia, 2011.

46. Standards Australia. Structural Design Actions. Part 4: Earthquake Actions in Australia; AS 1170.4; Standards Australia: New South Wales, Australia, 2007.

47. Standards Australia. AS 1530.4-2005 Part 4: Fire Resistance Test of Elements of Construction. In Methods for Fire Tests on Building Materials, Components and Structures; Standards Australia: Sydney, Australia, 2005.

48. Standards Australia. Fire Propagation Testing and Classification of External Walls of Buildings; AS 5113; Standards Australia: Sydney, Australia, 2016.

49. Building Code of Australia. National Construction Code; NCC 2016, Building Code of Australia: Canberra, ACT, Australia, 2016.

50. Williams, L.T. The Worst Bushfires in Australia's History. Available online: https://www. australiangeographic.com.au/topics/science-environment/2011/11/the-worst-bushfires-in-australiashistory/ (accessed on 11 October 2018).

51. Wang, Y.C. An analysis of the global structural behaviour of the Cardington steel-framed building during the two BRE fire tests. Eng. Struct. 2000, 22, 401-412. [CrossRef]

52. Nguyen, Q.T.; Ngo, T.D.; Tran, P.; Mendis, P.; Bhattacharyya, D. Influences of clay and manufacturing on fire resistance of organoclay/thermoset nanocomposites. Compos. Part A 2015, 74, 26-37. [CrossRef]

53. Nguyen, Q.T.; Ngo, T.; Tran, P.; Mendis, P.; Zobec, M.; Aye, L. Fire performance of prefabricated modular units using organoclay/glass fibre reinforced polymer composite. Constr. Build. Mater. 2016, 129, $204-215$. [CrossRef]

54. Nguyen, Q.T.; Ngo, T.; Tran, P.; Mendis, P.; Aye, L.; Baduge, S.K. Fire resistance of a prefabricated bushfire bunker using aerated concrete panels. Constr. Build. Mater. 2018, 174, 410-420. [CrossRef]

55. Lineham, S.A.; Thomson, D.; Bartlett, A.I.; Bisby, L.A.; Hadden, R.M. Structural response of fire-exposed cross-laminated timber beams under sustained loads. Fire Safety J. 2016, 85, 23-34. [CrossRef]

56. Barber, D. Determination of fire resistance rating for glulam connectors within US high rise timber buildings. Fire Safety J. 2017, 2017, 91. [CrossRef]

57. Annan, C.D.; Youssef, M.A.; El-Naggar, M.H. Seismic performance of modular steel braced frames. In Proceedings of the Ninth Canadian Conference on Earthquake Engineering, Ottawa, ON, Canada, 26-29 June 2007.

58. Annan, C.D.; Youssef, M.A.; El Naggar, M.H. Seismic Vulnerability Assessment of Modular Steel Buildings. J. Earthq. Eng. 2009, 13, 1065-1088. [CrossRef] 
59. Annan, C.D.; Youssef, M.A.; El Naggar, M.H. Seismic Overstrength in Braced Frames of Modular Steel Buildings. J. Earthq. Eng. 2008, 13, 1-21. [CrossRef]

60. Federal Emergency Federal Agency. FEMA-356, Pre-standard and Commentary for Seismic Rehabilitation of Buildings; Federal Emergency Federal Agency: Washington, DC, USA, 2000.

61. Lawson, R.M.; Ogden, R.G.; Pedreschi, R.; Popo-Ola, S.O. Development in prefabricated systems in light steel and modular construction. Struct. Eng. 2005, 83, 28-35.

62. Ramaji, I.J.; Memari, A.M. Identification of structural issues in design and construction of multistory modular buildings. In Proceedings of the 1st Residential Building Design \& Construction Conference, Pennsylvania Housing Research Center (PHRC), Bethlehem, PA, USA, 19-20 February 2013; pp. 294-303.

63. Bathon, L.; Bletz, O.; Schmidt, J. Hurricane proof buildings-An innovative solution using prefabricated modular wood concrete-composite elements. In Proceedings of the 9th World Conference on Timber Engineering, Portland, OR, USA, 6-10 August 2006.

64. Reardon, G.F. Simulated Cyclone Wind Loading of a Nu-Steel House Technical Report No. 36; Cyclone Testing Station, James Cook University: Townsville, Australia, 1990.

65. O'Connor, J.T.; O'Brien, W.J.; Choi, J.O. Industrial project execution planning: Modularization versus stick-built. Pract. Period Struct. Des. Constr. 2016, 21, 4015014. [CrossRef]

66. Ramaji, I.; Memari, A. Information exchange standardization for BIM application to multistory modular residential buildings. In Proceedings of the 6th Biennial Professional Conference (AEI 2015), Milwaukee, WI, USA, 24-27 March 2015; pp. 13-24.

67. Satheeskumar, N.; Henderson, D.J.; Ginger, J.D.; Humphreys, M.T.; Wang, C.H. Load sharing and structural response of roof-wall system in a timber-framed house. Eng. Struct. 2016, 122, 310-322. [CrossRef]

(C) 2019 by the authors. Licensee MDPI, Basel, Switzerland. This article is an open access article distributed under the terms and conditions of the Creative Commons Attribution (CC BY) license (http:// creativecommons.org/licenses/by/4.0/). 